\title{
Building An Experiential Learning Model For A Project Management Course
}

\author{
Kuan C. Chen, Purdue University Calumet, USA
}

Keh-Wen "Carin" Chuang, Purdue University North Central, USA

\begin{abstract}
Teaching students to become project management professionals requires a real world experience. Incorporating live clients into student projects, instead of using case studies or mock companies, adds a dimension that exposes students to the realities of project management. This paper will describe a structured methodology used in a project management course to learn a completed project life cycle. Based upon the written evaluations included with the final project documentation, students feel this project is the most valuable learning experience of the course. Furthermore, the positive relationship established with the clients allows this project to serve as a bridge between business and academe. This paper will discuss a variety of approaches to build an experiential learning model and provide a case study of a project management course using experiential learning to evolve a learning opportunity.
\end{abstract}

Keywords: Project management, Experiential learning, Real world experience, Project lifecycle.

\section{INTRODUCTION}

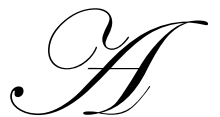

project management course involves three main elements: project life cycle instruction, project management theory, and real world experiences. Thus, the project management instructional model involves not only the knowledge conveyance, but also the experiential learning. Project management learning requires that students have opportunities to comprehend what they hear and read, as well as to express themselves in meaningful assignments or products. Creating an experiential learning environment for students becomes an important part of the course instruction. Generally speaking, the project management instructional model involves not only the knowledge conveyance, but also the skills training and real world experiences. Project management learning requires that students have opportunities to comprehend what they hear and read, as well as express themselves in meaningful assignments or products. Therefore, as a project management instructor, within regular class time, it is a big challenge to adopt pedagogy to pass on skills disciplines and also teaching theory foundation. One way to assess the validity of skills disciplines and extend our knowledge is through discourse with one another as members of an experiential learning approach. Experiential learning is the instructional use of a learning activity having a behavioral-based hierarchy that allows the student to experience and practice job-related tasks and functions during a class session. Experiential learning helps build and strengthen the knowledge and skills acquired through life, work experience and study which have not been formally attested through any educational or professional certification.

In this paper, building an experiential learning model in project management education is presented. At first, this paper will discuss a variety of approaches to build an experiential learning model and provide a case study of a project management course using experiential learning to evolve a learning opportunity. Specifically, the objective of this paper is to develop an integrated model of an experiential learning system model. The relationships in the model are designed to be simple and do not necessarily represent any particular experiential learning environment. It is meant to be a generic experiential learning system model with emphasis on implications for experiential learning instructional design. It allows experiential learning administrators to move away from the persistent belief that there are elements as unilateral causation, independent and dependent variables. 


\section{EXPERIENTIAL LEARNING}

Education focuses on the relationship between teaching and learning. According to Rogers (1969), learning is facilitated when: (1) the student participates completely in the learning process and has control over its nature and direction, (2) it is primarily based upon direct confrontation with practical, social, personal or research problems, and (3) self-evaluation is the principal method of assessing progress or success. Rogers also emphasizes the importance of learning as an openness to change. To Rogers, experiential learning is equivalent to personal change and growth. Rogers feels that all human beings have a natural propensity to learn and that the role of the teacher is to facilitate such learning. This includes: (1) setting a positive climate for learning, (2) clarifying the purposes of the learner(s), (3) organizing and making available learning resources, (4) balancing intellectual and emotional components of learning, and (5) sharing feelings and thoughts with learners, but not dominating. He lists the following as qualities of experiential learning: personal involvement, self-initiated, evaluated by learner, and pervasive effects on learner.

Experiential learning requires no teacher and relates solely to the meaning of "making process of the individual from direct experience". It is an inherent process that occurs naturally. It is a term often used mistakenly as a synonymous term for experiential education, action learning, adventure learning, free choice learning, cooperative learning, service learning, and many others. While there are relationships and connections, importantly they are also separate terms with separate meanings. Experiential learning is highly suited to the acquisition of practical skills where trial and error and the opportunity to practice practical techniques related to real tasks is essential.

John Dewey concluded that "all genuine education comes about through experience; this does not mean that all experiences are genuinely or equally educative" (1938). Dewey felt experience was a cycle of trying. One senses a concern, gets an idea, tries it out in an arena of applicability, undergoes or experiences the consequences, and confirms or reinterprets theory in the light of those consequences. In the best case, this process results in a reconstruction of experience, a re-codifying of habits, and an ongoing active questioning through further experimentation.

\section{PROJECT MANAGEMENT COURSE}

Since the majority of students in the class are new to project management, it is important to provide them with a framework for the project management lifecycle (See Figure 1). The methodology employed in the class adapts features of traditional project management methodologies to all project-based tasks.

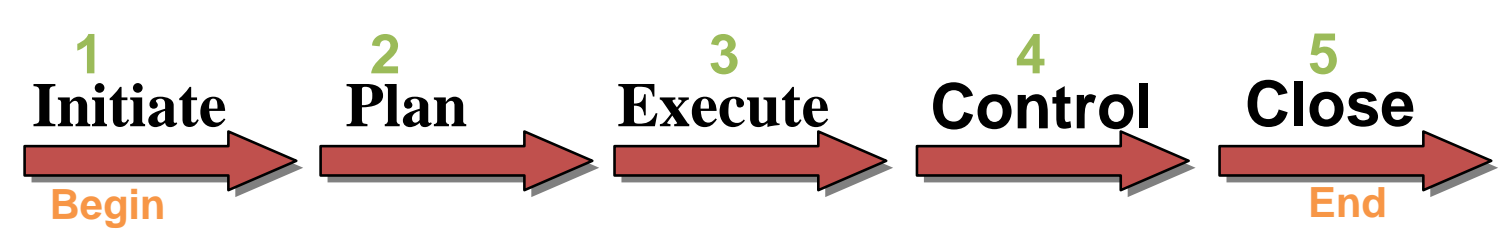

Figure 1: Project Management Life Cycle

The process begins with initiating activities that include: 1) define project scope, document project risks, assumptions, and constraints; 2) identify and perform stakeholder analysis; 3) develop project charter; and 4) obtain project charter approval. Next, the planning processes are: 1) define and record requirements, constraint, and assumption; 2) identify project team and define roles and responsibilities; 3 ) create the work breakdown structure; 4) develop a change management plan; and 5) identify risks and define risk strategies. The executing processes include: 1) execute tasks; 2) ensure common understanding and set expectations; 3) implement the procurement of project resources; 4) manage resource allocation; 5) implement a quality management plan; 6) implement approved changes; 7) implement approved actions and workarounds; and 8) and improve team performance. The processes of monitoring and controlling the project comprise of: 1) measuring project performance; 2) verifying and managing 
changes to the project; 3 ) ensuring that project deliverables conform to quality standards; and 4) monitoring all risks. Closing the project is the final stage of the life cycle and includes: 1) obtaining final acceptance; 2) obtaining financial and legal closure; 3) releasing project resources; 4) identifying lessons learned; 5) creating and distributing the final project report; and 6) measuring customer stratification.

\section{PROJECT MANAGEMENT COURSE IMPLEMENTATION}

This paper will provide a case discussion of a project management course using experiential learning to evolve learning environments. The general case will be presented in four phases: pre-planning, planning, implementation and evaluation.

\section{Pre-planning}

The most important concept of experiential learning is that the instructor plays a variety of roles -curriculum designer, tutor, resource and student/client communicator, and evaluator. The difference between traditional lecture and experiential learning is that the instructor's task in experiential learning is guiding without leading and assisting, and without directing.

The role of the students is also different from the traditional lecture classroom setting. They must become team players with peers to grab the concept and learn the skills, and they cannot afford to sit passively in the classroom and collect the information provided by the instructor.

This course describes the use of projects to support business objectives in modern organizations. At the end of this course, students should be able to develop, execute, and control a basic project plan capable of supporting business objectives linked to measures of success. The roles of the project manager and project team members will be covered as well. To this extent, students will engage in the following activities:

- $\quad$ Read assigned material prior to class sessions;

- $\quad$ Learn from the content of textbook and case study;

- $\quad$ Participate in a real world project;

- $\quad$ Complete milestone assignments;

- $\quad$ Complete examinations and a final presentation.

\section{Planning}

\section{Determine Students Experiential Learning Goals}

As an instructor, it is necessary to spend time reflecting on students' learning goals for obtaining an experiences. Consider these questions:

- $\quad$ Where do you want to have students' experiential learning? If students' experiential learning is during the day time, you obviously need a location close to your college campus. You may also wish to have a location in the area so that you can save on expenses for students or in a location where you hope to land a full-time position when students graduate -- or just to experience a place in which students have never lived before.

- What are student specific career interests? The learning experience is a great tool to help students define their career goals. For example, if they are majoring in a construction career, but have an eye on a construction project manager, you might consider experiential learning with a local or state construction project. A learning experience can also help further redefine their career goals. For example, if they are majoring in marketing but are not sure whether they want to go into advertising or public relations, the instructor should encourage the students to consider getting a learning experience in both areas to help them decide which is best for them. 
- What type of organization are you interested in? Organizations come in all sizes and shapes, from Fortune 500 companies to not-for-profit organizations. What are students looking for? Issues to consider include size, ownership, corporate culture, etc.

- $\quad$ What do you hope the students will gain from the experiences? There are multiple reasons for experiential learning, including answering the question above. Other possible reasons include: learning new skills, gaining networking connections, adding real world experience to a students' resume, and hoping it leads to a full-time position with the employer when the student graduates.

\section{Team Building}

When you assemble a team, you will bring together people who represent diverse experiences, skills, personalities and social backgrounds. Had you not brought these people together, they may not have naturally gravitated to one another to form friendships or social interaction. Yet, now these people must work together to achieve a specific objective. The instructor's job is to manage the interaction and unite these very different people to get the desired results.

The advantage is that the different experiences and skills provide you with tremendous opportunities to devise innovative solutions to the problem or task you face. The disadvantage is that the differences, if not managed properly, can create endless stumbling blocks and make it difficult to achieve any results.

To this extend, the first stage is to form teams. Although there are many good models to form a team, the general rules of thumb are skill and knowledge diversity, as well as personality. Skill and knowledge diversity can be found from student background checking in the first day of class. Managing a diverse group, particularly one that contains individuals with strong or abrasive personalities, can be broken into three steps:

1. Identify basic psychology/emotional needs that are common to all team members.

2. Establish limits and ground rules that will help you manage future problems.

3. Minimize differences and maximize shared interests and needs to build cohesiveness among themselves.

In the first two weeks, the students do not get into the main topics of the course. Instead, this time is spent building a team and a team-learning environment. Students learn how to build a team, build up the team goal and how to work on the team activities, as well as use the problem-solving tools and techniques. The instructor can take advantage of this stage to give students some pre-assessment to review the pre-knowledge they should have prior to taking this course.

\section{The Syllabus}

The syllabus can follow the traditional syllabus structure. However, the team rule and the experiential learning instructional model have to be included in the components. The team rule includes the team building approach, team goal, team activities implementation and grading method. Students new to the team style may get frustrated by what they perceive as a lack of structure, direction, and information. The experiential learning instructional model section must clearly communicate goals and expectations to the students. It also provides the guidance and structure in order to have students learn process skills and how to effectively function in teams.

\section{Implementations}

Pre-requisites of this course are project management skills and methodology. During the 16 weeks, the course will be divided into two eight weeks sections. The first eight weeks will be project management fundamental training in the classroom. Once students have acquired fundamental project management skills in the first 8 weeks and they know the recommended project management methodology, they embark on a team-oriented, real world project. As the instructor's responsibility, I would like to contact a project-oriented company for students to learn and implement the skills and methodology. The project-oriented industry companies include construction, academia, information systems, planning convention, marketing, fund-raising, etc. The project itself is divided into the following five milestones to help the students apply the scope, time, and cost constraints: 
- $\quad$ Team and project selection

- $\quad$ Analysis of competitors

- $\quad$ Project proposal and site design

- $\quad$ Prototype demonstration

- $\quad$ Group project presentation and final folder submission

\section{Evaluation}

Grading will be based on client assessment, team performance, and will also be adjusted for individual performance. Two peer performance assessments, three team exams, ten in-class assignments, and a self-assessment journal have to be developed. The peer performance assessments are administrated at the middle and end of the semester and can be developed using the Likert scale or open-end questions. More important is that it has to be quantified later.

An in-class team assignment is a good tool for equipping students on how to deal with specific puzzling problems that may surface. For example, in the programming language course, syntax debug and logic design are always a big headache to students. Therefore, give the team an assignment and allow them a few minutes to brainstorm for strategies to implement the language and logic design. List their ideas on the board, throwing in one or two of your own if you have any, then put the students back into their groups to try to reach consensus on the best strategies for what to do. Also, the in-class team assignment serves as the individuals' attendance and contribution to the team. Students can miss class a total of five times, including the ones they had accrued to that point; then each additional absence beyond the fifth would result in the student having his or her grade dropped one full letter, unless the absence was due to illness and accompanied by a doctor's excuse or a legitimate school function that was accompanied by an official explaining the purpose of the event and the date. Attendance usually improved dramatically from that point forward.

Often group conflicts stem from different expectations that team members have for one another. To get teams off to a good start, ask them to prepare a self-assessment journal. After a few weeks into the semester, ask the teams to revisit their journals and evaluate how well they are doing in meeting the expectations they set for themselves. A self-assessment journal is a good tool for equipping students on how to deal with specific interpersonal problems that may surface. For example, after the instructor has gotten a few complaints about the slackers, the instructor might ask each team member to review their self-assessment journals and them review them with the whole team. Then it is easy to expose the problem and build up the communication within the team.

\section{CONCLUSIONS}

As a project itself, running a course in project management is a great way for students to understand, apply, and reflect on the material. This experiential learning adds variety to this class by using the real world experience as a resource. Several teaching strategies to promote experiential learning include surveying different industries regarding project management in the Northwest Indian and Chicago areas, group hands-on projects, and other forms of on-site case studies to enhance teaching and learning, as well as encouraging outside studying.

Students are usually very interested in learning more about career options. Since many students have not considered becoming project managers, nor have they thought about their roles as project team members, it would be beneficial to visit a company project office to discuss what it is like to be a project manager. Furthermore, working with industry project managers would grasp the knowledge that is impossible to learn from a textbook and classroom setting, such as conflict management, triple-constraints trade-off, etc.

\section{AUTHOR INFORMATION}

Kuan C. Chen, Ph.D. is Head of Department Information Systems in the School of Management at Purdue University Calumet in Hammond, Indiana. Dr. Chen has extensive experience in MIS research topics. He has authored numerous journal papers on topics varying from project management to Information Technology (IT) economics. He has also been a contributing author on several books and a technical editor on numerous books and 
journal articles. Dr. Chen maintains an active Web development and database consulting practice in both the U.S. and Taiwan. He has a Ph.D. in Information Systems and another Ph.D. in Applied Economics, both from Michigan State University.

Keh-Wen (Carin) Chuang, MS. is an assistant professor in the Department of Computer \& Information Technology at Purdue University North Central. Before entering academia, Professor Chuang has been spent over 12 years of professional experience in database administration and information system development for three Fortune 100 companies in Illinois, Indiana and Michigan. Professor Chuang is a certified JAVA developer, SQL Server Administrator and E-Commerce Web Site Developer.

Professor Chuang earned her two Master degrees in Information Systems and Urban Studies at Michigan State University, and her BBA in International Economics from Soochow University at Taiwan.

\section{REFERENCES}

1. Combs, A.W. (1982). Affective education or none at all. Educational Leadership, 39(7), 494-497.

2. Dewey, J. (2007). What is Experiential Learning? http://people.uleth.ca/ steve.craig/

3. Deutsch, M. (1962). Cooperation and trust: Some theoretical notes. In M. R. Jones (Ed.), Nebraska symposium on motivation, 275-319. Lincoln, NE: University of Nebraska Press.

4. Felder, R. M. \& Brent, R. (2001) Effective strategies for cooperative learning. Journal of Cooperation \& Collaboration in College Teaching, 10(2), 69-75.

5. Johnson, D. W. (1993). Reaching out: Interpersonal effectiveness and self-actualization (6th Ed.). Needham Heights, MA: Allyn \& Bacon.

6. Johnson, D. W., \& Johnson, R. T. (1989). Cooperation and competition: Theory and research. Edina, MN: Interaction Book Company.

7. Johnson, D. W., \& Johnson, R. T. (1995). Teaching students to be peacemakers (3rd Ed.). Edina, MN: Interaction Book Company.

8. Kolb, D. (2008). David Kolb's learning styles model and experiential learning theory (ELT). http://www.businessballs.com/kolblearningstyles.htm

9. $\quad$ Patterson, C.H. (1973). Humanistic Education. Englewood Cliffs, NJ: Prentice-Hall.

10. Rogers, C.R. (1969). Freedom to Learn. Columbus, OH: Merrill.

11. Rogers, C.R. \& Freiberg, H.J. (1994). Freedom to Learn (3rd Ed). Columbus, OH: Merrill/Macmillan.

12. Rogers, C.R. (2007) Experiential Learning. http://tip.psychology.org/rogers.html

13. Ricketts, M., \& Willis, J. (2002). The power of experiential learning. http://www.teambuildingguru.com

14. Saddington, A. (2003). What is Experiential Learning? http://www.el.uct.ac.za/

15. Smith, M. K. (2001). David A. Kolb on experiential learning. the encyclopedia of informal education, http://www.infed.org/b-explrn.htm

16. Smith, M. K. (2003). Introduction to informal education. the encyclopedia of informal education, http://www.infed.org/i-intro.htm

17. Valett, R.E. (1977). Humanistic Education. St Louis, MO: Mosby. 